\title{
KETIMPANGAN DIGLOSIK DALAM PERISTIWA TUTUR MASYARAKAT MULTILINGUAL MESUJI RAYA SUMATERA SELATAN
}

\author{
Muslihah $^{1}$, Muhammad Suryadi ${ }^{2}$ \\ Universitas Diponegoro, ${ }^{1,2}$ \\ muslihah.nazwa@gmail.com ${ }^{1}$
}

Submit, 31-10-2019 Accepted, 22-12-2019 Publish, 23-12-2019

\begin{abstract}
ABSTRAK
Tujuan dari penelitian ini adalah untuk menjelaskan situasi kebahasaan berupa ketimpangan diglosik yang terjadi dalam peristiwa tutur masyarakat Jawa di wilayah Mesuji Raya. Metode yang digunakan dalam penelitian ini adalah deskriptif kualitatif. Tahapan-tahapan dalam penelitian ini diawali dengan pengumpulan data yang dilakukan dengan teknik observasi, wawancara, dan teknik catat. Data pada penelitian ini adalah berupa tuturan alami yang digunakan oleh masyarakat tutur Jawa Mesuji Raya. Tahapan selanjutnya adalah tahapan analisis data yaitu dilakukan dengan metode padan. Hasil yang didapat setelah melakukan analisis data adalah kode bahasa Jawa dan bahasa Indonesia memiliki kedudukan sebagai bahasa pengantar sesama etnis Jawa di Mesuji Raya dan berkedudukan sebagai ragam tinggi (T) dan ragam rendah (R), penutur Jawa di wilayah ini cenderung kurang memahami penggunaan kode bahasa Jawa secara benar, dan pemahaman serta pemahaman kosakata yang dimiliki oleh masyarakat Jawa di Mesuji Raya dalam ragam krama masih rendah. Simpulan, penggunaan kode ragam rendah $(R)$ juga digunakan sebagai sarana alih kode pada tuturan ragam tinggi $(T)$ hal ini sebabkan karena faktor linguistik yaitu keterbatasan kemampuan yang dimiliki oleh penutur.
\end{abstract}

Kata Kunci : Ketimpangan Diglosik, Masyarakat Multilingual, Mesuji Raya

\section{ABSTRACT}

The purpose of this research is to explain the linguistic situation in the form of diglossic inequality in speech events that occur in the Mesuji Raya. The method used in this research is descriptive qualitative. The stages in this study began with data collection conducted by observation, interview, and note taking techniques. The data in this study consisted of natural utterances used by the Javanese Mesuji Raya speech community. The next stage is the stage of data analysis carried out by the matching method. The results obtained after analyzing the data are Javanese and Indonesian language codes have the Javanese language of instruction in Mesuji Raya and the seat is of a high variety $(T)$ and the low variance code $(R)$, Javanese speakers in this region do not like to use Javanese language codes correctly, and Understand also Understanding the language given by the Javanese people in Mesuji Raya in the various manners is still low. Conclusion, the use of the low variance code $(R)$ is also used as a means of code switching in high variance speech $(T)$, this is caused by linguistic factors, namely the ability of utilization required by the speaker.

Keywords: Diglosic Inequality, Multilingual Society, Mesuji Raya. 


\section{PENDAHULUAN}

Mesuji Raya dihuni oleh berbagai etnik yang berasal dari beberapa daerah di Indonesia. Beberapa etnik yang tinggal di wilayah ini di antaranya berasal dari Jawa, Sunda, Bali, Lampung, dan penduduk asli. Penduduk asli daerah ini adalah seperti dari etnik Ogan, Komering, dan Pegagan. Dengan adanya masyarakat pendatang menempati wilayah ini menyebabkan terjadinya akulturasi budaya dan bahasa. Adanya akulturasi budaya dan bahasa dari penduduk pendatang membuat masyarakat di kecamatan Mesuji Raya mengenal lebih dari satu kode atau satu macam ragam bahasa. Hal ini membuat masyarakatnya disebut sebagai masyarakat bilingual atau multilingual. Fenomena ini terjadi dikarenakan masyarakatnya tidak hanya menggunakan satu kode atau satu ragam saja dalam kehidupan keseharian mereka, melainkan lebih dari satu kode atau bahasa.

Seseorang yang melakukan interaksi dengan dua bahasa dapat dikatakan sebagai bilingualisme. Kemampuan yang dimiliki oleh seorang penutur dalam memahami dua kode bahasa tersebut dikenal dengan istilah kedwibahasaan. Sebenarnya istilah kedwibahasaan ini pertama kali kemukakan oleh Bloomfield (Rokhman, 2015) ia berpendapat bahwa kedwibahasaan atau bilingualisme adalah kemampuan yang dimiliki penutur bahasa dalam menggunakan dua bahasa dengan kefasihan yang sama baiknya.

Adanya berbagai macam kode dan ragam bahasa tersebut menyebabkan penutur bahasa harus memiliki kemampuan untuk memilih dan menentukan kode atau ragam yang sesuai untuk digunakan. Situasi kebahasaan seperti ini disebut sebagai situasi diglosik (Sumarsono, 2013).

Pada awalnya istilah diglosia berasal kata diglossie kemudian dikenalkan oleh Ferguson (1959) dengan bahasa Inggris yang dikenal dengan istilah diglosia (Astuti, 2017). Berkat penelitian yang dilakukan oleh Ferguson maka pemakaian istilah diglosia semakin populer dan dikenal oleh para ahli sosiolinguistik. Diglosia yang dipopulerkan oleh Ferguson tersebut membahas mengenai bahasa yang dianggap sebagai ragam tinggi (T) atau high (H) dan ragam rendah (R) atau Low (L) (Agustina \& Zulkifli, 2014). Fishman (dalam Wahab, 2013) mengemukakan bahwa diglosia tidak terjadi hanya dalam satu bahasa atau dua ragam bahasa, melainkan mengacu pada perbedaan linguistik seperti apapun bentuknya. Oleh karena itu menurut Fishman, diglosia dapat terjadi pada dua bahasa yang benar-benar berbeda. 
Pada masyarakat yang bilingual atau multilingual dalam memilih dan menentukan kode yang akan digunakan tentu dilakukan berdasarkan pertimbangan. Kode atau ragam yang dipilih yaitu kode yang dianggap sesuai dengan konteks dan situasi dalam peristiwa tutur yang sedang terjadi. Oleh karena itu setiap individu akan memiliki karakteristik dan cara penyampaian pesan yang berbeda-beda tergantung dari konteksnya. Rustono (1999) menjelaskan bahwa konteks dapat menjelaskan atau menggambarkan sebuah maksud tuturan yang ingin disampaikan penutur.

Menurut Iriyansah (2019) dalam konteks kasual atau situasi informal seorang penutur tidak hanya menggunakan satu ragam bahasa $(\mathrm{R})$ melainkan penggunaan ragam tinggi (T) juga digunakan sekaligus dalam satu peristiwa tutur. Penelitiannya menunjukkan bahwa ragam krama lugu merupakan wujud ragam yang muncul sebagai ragam tinggi (T). Penggunaan ragam bahasa pada masyarakat dengan hubungan sosial tidak asimetris atau tidak akrab dilihat berdasarkan pendidikan, pekerjaan, dan jabatan. Pada penelitiannya tersebut membahas mengenai situasi diglosia yang terjadi hanya pada ranah pertemanan berdasarkan status sosial penutur. Hal ini yang membedakan dengan penelitian ini. Dengan melihat penggunaan kode dalam ranah lain dalam penelitian ini maka akan diketahui lebih jelas bagaimana situasi diglosia yang terjadi pada masyarakat Jawa yang tinggal di Mesuji Raya.

Astuti (2017) melakukan penelitian mengenai diglosia yang berfokus pada penggunaan bahasa Arab. Dalam penelitiannya membahas mengenai diglosia pada penggunaan bahasa Arab secara umum. Hasil penelitiannya yaitu diketahui bahwa pada forum dan media yang bersifat formal bahasa Arab Fusha menjadi pilihan bahasa yang tepat, dan pada komunikasi keseharian yang bersifat non-formal biasa digunakan bahasa Arab Amiyah.

Penelitian ini ingin melihat dari tiga ranah penggunaan bahasa. Ranah penggunaan bahasa tersebut yaitu ranah pertemanan, pendidikan, dan transaksi jual-beli. Kemudian penelitian terdahulu mengenai diglosia pada penggunaan bahasa Arab belum terlalu mendalam, ia tidak menggunakan tuturan yang digunakan oleh penutur bahasa secara langsung. Melainkan hanya berupa deskripsi mengenai teori-teori tanpa menampilkan contoh data penggunaan bahasa.

Sejauh pengetahuan peneliti, penelitian mengenai situasi diglosia pada masyarakat di wilayah Mesuji Raya juga belum pernah dilakukan oleh peneliti bahasa 
sebelumnya. Oleh karena itu, peneliti mengungkap situasi diglosia yang ada dalam peristiwa tutur masyarakat multilingual di Mesuji Raya melalui penelitian ini.

\section{METODE PENELITIAN}

Metode yang digunakan dalam penelitian ini adalah deskriptif kualitatif. Datadata dikumpulkan secara purposive random sampling. Tahapan-tahapan yang dilakukan yang pertama adalah tahap pengumpulan data dilakukan dengan metode simak dan dilanjutkan dengan teknik cakap. Metode simak yaitu dengan mengamati penggunaan bahasa secara natural oleh masyarakat tutur Jawa di Mesuji Raya tanpa terlibat dalam peristiwa tutur yang disebut dengan teknik simak bebas libat cakap. Dalam melakukan pengamatan dengan metode simak dilakukan juga perekaman menggunakan alat rekam/recorder agar data yang sudah didapat nantinya dapat diawetkan atau dapat diputar kembali apabila dibutuhkan pada saat analisis data. Pada saat perekaman dilakukan pencatatan konteks dan hal-hal yang berhubungan dengan peristiwa tutur yang direkam.

Tahapan selanjutnya adalah tahapan analisis data, yaitu merupakan tahapan yang dilakukan setelah proses pengumpulan data selesai dilakukan. Tahapan ini dilakukan dengan cara memutar kembali data rekaman kemudian dilakukan transkripsi data. Data berupa tulisan berdasarkan hasil tuturan alami yang dilakukan oleh masyarakat tutur Mesuji Raya ini kemudian dianalisis dengan menggunakan metode padan. Setelah proses identifikasi dan analisis data selesai dilakukan maka selanjutnya dilakukan penarikan kesimpulan hasil analisis data. Tahapan terakhir adalah tahap penyajian hasil analisis data berupa kata-kata

\section{HASIL PENELITIAN}

Masyarakat tutur di Mesuji Raya dapat diidentifikasi memiliki repertoar lebih dari satu bahasa, yaitu terutama bahasa Indonesia dan bahasa ibu (bahasa pertama) mereka atau bahkan bahasa dari etnis lain baik dari masyarakat asli yang tinggal di wilayah tersebut yaitu bahasa Melayu Palembang atau bahasa Jawa dan bahasa Bali yang merupakan bahasa penduduk pendatang. Namun masyarakat etnis Jawa yang tinggal di wilayah ini cenderung mempertahankan eksistensi kode Jawa meskipun di 
wilayah migrasi. Masyarakat Jawa dalam kategori usia tua masih mengajarkan kode Jawa kepada anak-anak mereka.

\section{Ranah Pertemanan/Tetangga}

Masyarakat tutur Mesuji Raya terutama dari etnis Jawa pendatang, cenderung menggunakan kode bahasa Jawa ketika berinteraksi dengan penutur yang memiliki latar belakang etnis yang sama.

P1 : Dientosi nggak apa-apa dilit, daripada anu.. dienteni ndisek neng omah.

'Ditunggu ngga apa-apa sebentar, daripada emm.. ditunggu bentar di rumah'

P2 : Pundi surate, tak lihat sek coba

'Mana suratnya, saya lihat dulu coba'

P3 : Surat'e ki nggak enek mbak.

'Suratnya itu nggak ada mbak'

Konteks Sosiokultural : Percakapan data tersebut dilakukan oleh tiga orang di ruang tamu. P1 adalah laki-laki berusia 47 tahun, P2 merupakan seorang anak perempuan berusia 22 tahun, dan P3 adalah tamu laki-laki berusia 36 tahun. Ketiganya merupakan masyarakat Jawa.

Partisipan yang terlibat dalam peristiwa tutur tersebut P1, P2 dan P3 merupakan masyarakat dari etnis Jawa. P1 dan P2 adalah tuan rumah, sedangkan P3 merupakan tamu yang belum dikenal sebelumnya. Berdasarkan konteks, penggalan percakapan data di atas diketahui bahwa pembicaraan sebelumnya diawali dengan menggunakan kode Jawa dengan ragam krama sebagai ragam tinggi (T) itu terjadi antara P2 dan P3 yaitu tamu dan tuan rumah. Namun, tampak dari data tersebut tuturan P1 menunjukkan adanya ketimpangan dalam kondisi diglosik dalam penentuan kode yang digunakan.

Ketimpangan tersebut terlihat pada penggunaan kode Jawa ragam krama dan ngoko serta penggunaan kode bahasa Indonesia sekaligus dalam satu tuturan. Tuturan dientosi yang termasuk ke dalam tingkat tutur krama bahasa Jawa bercampur dengan bahasa Indonesia dan ngoko sebagai ragam rendah (R). Hal ini dilakukan P1 dan P2 karena dilatarbelakangi ketidakmampuan penutur dalam penguasaan kode krama atau kompetensi yang dimiliki penutur rendah dalam penguasaan kode tersebut. 
Pemilihan kode yang di dalamnya terdapat ketimpangan diglosia seperti contoh pada data di bawah ini, penggunaan kode atau ragam yang bercampur dalam sebuah tuturan tampak pada tuturan yang digunakan oleh para penutur berikut ini.

P1 : Nggih, niki wau kan memang rencanane kulo memang ajeng njaluk tanda tangan pak kades niki wau. Karo Ya Allah niki sedikit-sedikit lah bantu desa aku ngono kan.

'Iya, ini tadi kan memang rencananya saya memang mau minta tanda tangan Pak Kades ini tadi. Sama Ya Allah ini sedikit-sedikit lah bantu desa aku gitu kan'

P2 : Kulo ra penak, maksud e ngoten kan. Mba Siti mireng nopo? tapi kulo nggih namuk ngomong kaleh Bapak mosok krungu.

'Saya engge enak, maksudnya gitu kan. Mba siti tau apa? tapi saya ya hanya bilang sama Bapak masa dengar'

P1 : Engga ah, engga ada, ngga mireng nopo-nopo.

'Engga ah, engga ada, engga dengar apa-apa'

Konteks Sosiokultural : Pihak-pihak yang terlibat dalam percakapan tersebut adalah antara ibu kepala desa dan seorang bidan di rumah kepala desa. P1 dan P2 merupakan etnis Jawa. P1 berusia 43 tahun, P2 berusia 38 tahun.

Pihak yang terlibat dalam peristiwa tutur tersebut P1 dan P2 adalah teman dengan hubungan yang tidak begitu dekat. Berdasarkan konteks percakapan data di atas topik yang sedang dibicarakan adalah mengenai makanan. Diketahui pembicaraan dimulai dengan menggunakan kode Jawa ragam krama yaitu pada tuturan $\boldsymbol{n g g i h}$, niki wau... yang artinya 'iya ini tadi...'. Namun, tampak dari data tersebut tuturan P1 menunjukkan adanya ketimpangan dalam diglosik dalam pemilihan kode yang digunakan oleh peserta tutur.

Penggunaan kosakata ngoko dalam tuturan krama seperti kata njaluk, karo, ngono, krungu, dan sufix $\sim$ ne pada kata rencanane menunjukkan bahwa tuturan tersebut dipengaruhi oleh kode Jawa ragam ngoko dan bahasa Indonesia. Oleh karena itu, sebenarnya para partisipan dalam percakapan tersebut bermaksud menuturkan tuturan dalam kode Jawa ragam krama yang dianggap berprestise dan sebagai bentuk sopan untuk menghormati lawan bicara sebagai ragam tinggi (T). Namun, karena keterbatasan kompetensi yang dimiliki para penutur sehingga mereka menggunakan campur kode ragam ngoko yang merupakan ragam rendah (R) dan campur kode bahasa Indonesia sebagai ragam tinggi $(\mathrm{T})$ dalam tuturan ragam krama $(\mathrm{T})$.

Pada pemilihan kode tersebut terjadi ketimpangan tidak hanya pada penggunaan kode Jawa ragam krama dan ngoko, namun terdapat penggunaan kode 
bahasa Indonesia sekaligus dalam satu tuturan. Hal ini dilakukan penutur karena dilatarbelakangi ketidakmampuan penutur dalam penguasaan kode krama atau kompetensi yang dimiliki penutur rendah dalam penguasaan kode krama tersebut.

Peristiwa tutur berikut ini adalah salah satu contoh percakapan yang terjadi antara penutur yang memiliki latar belakang usia berbeda dan memiliki status sosial berbeda. Contoh tuturan tersebut adalah sebagai berikut.

P1 : Pangkalan Lampam? kae sing nyebrang kae nggo ketek (kapal motor kecil).

'Pangkalan Lampam? Itu yang nyebrang itu pake ketek'.

P2 : Air Sugihan Pak.

P1 : Air Sugihan kae yo sing ngetek?

'Air Sugihan itu ya yang ngetek?'

P2 : Nggih.

'iya'

P3 : Pampangan niki lho Pak sehabis SP (nama desa) niki.

'Pampangan ini lho Pak sehabis SP ini'

P1 : Jare ngetek ki, berarti Air Sugihan

'Katanya naik ketek tu, berarti Air Sugihan'

Konteks Sosiokultural : Percakapan data tersebut dilakukan oleh tiga orang di ruang tamu. P1 adalah laki-laki berusia 46 tahun, P2 merupakan seorang laki-laki berusia 32 tahun, dan P3 adalah laki-laki berusia 30 tahun. Ketiganya merupakan etnis Jawa.

Berdasarkan konteks, partisipan dalam percakapan data di atas sedang membicarakan topik tidak resmi. Diketahui dalam pembicaraan tersebut P1 menggunakan ragam ngoko $(\mathrm{R})$ dan $\mathrm{P} 2$ dan $\mathrm{P} 3$ memilih menggunakan kode Jawa ragam krama $(\mathrm{T})$. Dimulai dengan menggunakan kode Jawa ragam krama yaitu pada tuturan nggih, niki yang artinya 'iya, ini'. Namun, tampak dari data tersebut tuturan P3 menunjukkan adanya ketimpangan dalam kondisi diglosik dalam penentuan kode yang digunakan.

Penggunaan kosakata bahasa Indonesia seperti kata sehabis menunjukkan bahwa tuturan tersebut dipengaruhi oleh kode bahasa indonesia. Oleh karena itu, sebenarnya para partisipan dalam percakapan tersebut bermaksud menuturkan tuturan dalam kode Jawa ragam krama yang dianggap sebagai bentuk sopan untuk menghormati lawan bicara sebagai ragam tinggi (T). Namun, karena keterbatasan kompetensi yang dimiliki para penutur sehingga mereka menggunakan campur kode bahasa Indonesia dalam tuturan ragam krama yang merupakan ragam Tinggi (T). 
Ketimpangan pemilihan kode tersebut terjadi pada penggunaan kode bahasa Indonesia dalam kode ngoko sekaligus dalam satu tuturan. Hal ini dilakukan penutur karena dilatarbelakangi kompetensi yang dimiliki penutur dalam penguasaan kode krama oleh penutur masih rendah dalam penguasaan kode krama tersebut. Sehingg menyebabkan terjadinya ketimpangan diglosia dalam penggunaan bahasa oleh penutur. Selanjutnya peristiwa tutur berikut adalah salah satu contoh percakapan yang terjadi pada ranah pendidikan. Contoh tuturan tersebut adalah sebagai berikut.

\section{Ranah Pendidikan}

Pada ranah pendidikan, penentuan kode cenderung menggunakan kode BI yang di dalamnya bercampur juga dengan kode lain yaitu terutama kode BJ. Penutur Jawa yang multilingual cenderung menggunakan pola seperti ini meskipun dalam situasi resmi ataupun tidak resmi di ruang kelas. Namun, dalam situasi di kantor atau ruang guru, penutur Jawa juga tidak sedikit yang menggunakan pola sebaliknya. Contoh penggunaan kode dalam pendidikan yaitu seperti dalam percakapan berikut ini.

P1 : Itu kalo sudah ada ya. Arek gawe RPP kok anu to. Dataku entek. 'Itu kalau sudah ada ya. Mau buat RPP kok anu sih. Dataku habis'

P2 : Nggih ndamel RPP, kulo nggih dereng ndamel RPP og Pak. Mangkeh wedine dua hari besok langsung 'dikumpulkan RPPnya' waduh. 'Iya buat RPP, saya juga belum buat RPP Pak. Nanti takutnya dua hari besok langsung 'dikumpulkan RPPnya' waduh'

P1 : Tibakno wifine ga bisa to wifine. 'Ternyata wifinya ga bisa ya wifinya'

Konteks Sosiokultural : Percakapan tersebut dilakukan oleh dua orang guru di kantor atau ruang guru. Partisipan yang terlibat dalam percakapan yaitu P1 seorang lakilaki berusia 30 tahun, dan P2 laki-laki berusia 24 tahun.

Percakapan tersebut diawali dengan P1 yang menggunakan kode bahasa Indonesia ragam santai (T) yaitu pada tuturan itu kalo sudah ada ya. Berdasarkan konteks, partisipan dalam percakapan data di atas sedang membicarakan topik resmi yaitu mengenai RPP (Rancangan Pelaksanaan Pembelajaran) untuk pengajaran. Dari data tersebut diketahui P1 menggunakan bahasa Indonesia ragam santai yang dianggap sebagai bahasa tinggi di sekolah (T). Sementara P2 memilih menggunakan kode Jawa ragam krama juga sebagai ragam bahasa tinggi (T). Namun, tampak dari data tersebut tuturan P2 menunjukkan adanya ketimpangan dalam kondisi diglosik dalam penentuan kode yang digunakan. 
Kode bahasa Indonesia seperti pada tuturan dua hari besok langsung menunjukkan bahwa tuturan dipengaruhi oleh kode bahasa Indonesia. Oleh karena itu, keterbatasan kompetensi yang dimiliki para penutur menyebabkan mereka menggunakan campur kode bahasa Indonesia dalam tuturan ragam krama yang merupakan ragam tinggi (T). Karena pada awalnya P2 dalam percakapan tersebut bermaksud menuturkan tuturan dalam kode Jawa ragam krama yang dianggap sebagai bentuk sopan untuk menghormati lawan bicara sebagai ragam tinggi (T).

Berdasarkan data, dapat dikatakan bahwa ketimpangan diglosik pada pemilihan kode terjadi pada penggunaan kode bahasa Indonesia dalam kode krama yang terjadi pada satu peristiwa tutur. Hal ini dilakukan penutur karena dilatarbelakangi ketidakmampuan penutur dalam penguasaan kode krama atau kompetensi yang dimiliki penutur rendah dalam penguasaan kode krama tersebut. Selanjutnya peristiwa tutur berikut adalah salah satu contoh percakapan yang terjadi pada ranah tranksaksi jual-beli.

\section{Ranah Transaksi Jual-Beli}

Masyarakat tutur Jawa lebih banyak menggunakan kode BJ di ranah transaksi jual-beli apabila mereka berinteraksi dalam lingkup desa mereka. Namun untuk interaksi di luar desa masyarakat Jawa memilih menggunakan bahasa campuran, dapat berupa kode BI yang bercampur kode BJ dan kode melayu Palembang.

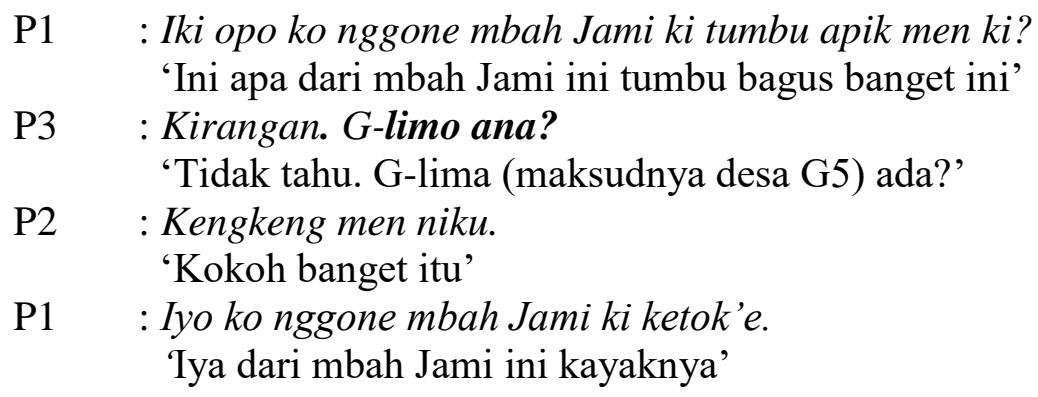

Konteks Sosiokultural : Latar pada peristiwa tutur data tersebut adalah di sebuah warung. Partisipan yang terlibat dalam percakapan yaitu P1 seorang perempuan 65 tahun, P2 perempuan berusia 24 tahun yang merupakan anak dari P1, serta P3 yaitu perempuan berusia 54 tahun.

Peristiwa tutur data tersebut diawali dengan P1 yang menggunakan kode Jawa ragam ngoko atau santai (R). Berdasarkan konteks, partisipan dalam percakapan data di atas sedang membicarakan topik tidak resmi atau kasual. Dari data tersebut diketahui P1 
menggunakan bahasa Jawa ragam ngoko yang dianggap sebagai bahasa rendah dalam ranah transaksi jual-beli (R). Sementara P2 memilih menggunakan kode Jawa ragam krama yang dianggap sebagai bahasa tinggi (T). Namun, tampak dari data tersebut tuturan P2 menunjukkan adanya ketimpangan dalam kondisi diglosik pemilihan bahasa atau dalam penentuan kode yang digunakan.

Penggunaan kode Jawa ngoko seperti limo ana menunjukkan bahwa tuturan krama tersebut dipengaruhi oleh kode bahasa Jawa ragam ngoko. Oleh karena itu, keterbatasan kompetensi yang dimiliki penutur menyebabkan ia menggunakan campur kode ngoko dalam tuturan ragam krama yang merupakan ragam Tinggi (T). Hal ini dapat dilihat dari penggunaan kosakata kirangan yang memiliki arti 'tidak tahu' termasuk ke dalam kosakata kode Jawa ragam krama. Pada awalnya P2 dalam percakapan tersebut bermaksud menuturkan tuturan dalam kode Jawa ragam krama yang dianggap sebagai bentuk sopan untuk menghormati lawan bicara sebagai ragam tinggi $(\mathrm{T})$. Berdasarkan data, hal tersebut dilakukan penutur karena dilatarbelakangi ketidakmampuan penutur dalam penguasaan kode krama atau kompetensi yang dimiliki penutur rendah dalam penguasaan kode krama tersebut.

\section{PEMBAHASAN}

Kode bahasa Jawa dominan digunakan oleh masyarakat tutur Jawa apabila berinteraksi dengan sesama masyarakat tutur Jawa lainnya dalam berbagai situasi, topik dan dalam ranah apapun. Hal ini terbukti dalam berbagai topik pembicaraan baik resmi maupun tidak resmi kode BJ selalu digunakan. Hasil Penelitian ini selaras dengan hasil penelitian Yusuf (2017) yang melakukan penelitian mengenai pemilihan kode pada masyarakat tutur Jawa pendatang di Ulin Banjarbaru. Hasil penelitiannya menyebutkan bahwa bahasa komunikasi yang digunakan oleh orang Jawa dengan orang dari tempat asal adalah bahasa Jawa. Alasan pertamanya yaitu karena memang kode bahasa Jawa merupakan bahasa Ibu atau bahasa pertama yang dikuasai oleh setiap masyarakat tutur bahasa Jawa merupakan bahasa Ibu atau bahasa pertama yang dikuasai oleh setiap masyarakat tutur Jawa yang tinggal di wilayah transmigran. Bahasa yang digunakan ketika berbicara dengan lawan tutur yang berasal dari etnis yang berbeda biasanya tidak menutup kemungkinan juga kode bahasa Jawa, kode bahasa Indonesia atau kode bahasa daerah lain. Kode ngoko dan kode bahasa Indonesia dianggap sebagai ragam (R), sedangkan kode krama sebagai ragam bahasa tinggi (T). 
Berdasarkan hasil analisis data, penggunaan kode atau bahasa yang dominan dalam ranah pendidikan adalah kode bahasa Indonesia untuk interaksi di dalam kelas. Hal tersebut selaras dengan penelitian yang dilakukan pada masyarakat Batak pendatang di Binjai Kalimantan Barat oleh Simarmata (2012). Pemilihan kode ini dilatarbelakangi oleh kode bahasa Indonesia yang dianggap sebagai bahasa resmi negara dan sebagai pengantar dalam dunia pendidikan. Namun dalam situasi di kantor atau di ruang guru, kode yang dominan digunakan adalah kode Jawa apabila berinteraksi sesama Jawa, meskipun terdapat percampuran antara kode tingkat Jawa ngoko maupun krama, dengan kode bahasa Indonesia ataupun dengan kode lainnya. Penutur Jawa dengan kategori usia muda, menggunakan kode bahasa Jawa krama ketika berbicara dengan lawan tutur Jawa yang lebih tua. Namun, dalam menentukan kode pun terjadi ketimpangan dikarenakan kemampuan bahasa yang dimiliki penutur rendah dalam memahami kode tersebut. Pada interaksi sesama masyarakat Jawa oleh pengajar, penggunaan ragam krama dianggap memiliki kedudukan lebih tinggi (T) dari pada kode bahasa Indonesia (R).

Penggunaan kode atau bahasa yang dominan dalam ranah pekerjaan terutama dalam transaksi jual beli adalah kode Jawa, meskipun terdapat percampuran antara kode tingkat ngoko dan krama, dengan kode bahasa Indonesia ataupun dengan kode lainnya. Sementara penggunaan bahasa pada instansi-instansi perkantoran misalnya seperti di kantor desa, kantor kecamatan, puskesmas, bank, dan koperasi cenderung menggunakan kode bahasa Indonesia. Kode bahasa Indonesia dianggap sebagai ragam bahasa tinggi (T). Penggunaan kode bahasa Indonesia tersebut dipilih oleh masyarakat tutur Jawa apabila bertutur dengan berbeda suku. Oleh karena itu, dalam ranah pekerjaan masyarakat tutur Jawa cenderung dipengaruhi oleh kode bahasa Indonesia atau kode bahasa lain seperti kode bahasa Sunda dan kurang memahami tingkat tutur krama dalam bahasa Jawa.

\section{SIMPULAN}

Penutur Jawa di Mesuji Raya kurang memahami penggunaan undha-usuk dalam kode bahasa Jawa secara benar. Pemahaman dan pembendaharaan kosakata dalam ragam krama juga masih rendah, terutama untuk penutur yang termasuk dalam usia muda. Oleh karena itu, penggunaan atau pemilihan kode yang dilakukan oleh masyarakat Jawa di Mesuji Raya terjadi ketimpangan dalam kondisi diglosik untuk menentukan kode yang sesuai dengan situasi tutur, sehingga penggunaan kode ragam 
rendah (R) juga digunakan sebagai sarana alih kode pada tuturan ragam tinggi $(\mathrm{T})$ hal ini sebabkan karena faktor linguistik yaitu keterbatasan kemampuan yang dimiliki oleh penutur.

\section{DAFTAR PUSTAKA}

Agustina, L., \& Zulkifli. (2014). Situasi Diglosia Pada Penutur Bahasa Ngaju Di Kecamatan Katingan Tengah Kabupaten Katingan Kalteng (Diglosia Situation On The Ngaju Language Speakers In Katingan Regency Central Katingan SubDistrict Of Central Kalimantan). Jurnal Bahasa, Sastra Dan Pembelajarannya, 4(2), 203-212. https://doi.org/10.20527/jbsp.v4i2.3693

Astuti, W. (2017). Diglosia Masyarakat Tutur Pada Penggunaan Bahasa Arab (Kajian Kebahasaan Terhadap Bahasa Fusha Dan Bahasa 'Amiyah Dilihat Dari Perspektif Sosiolinguistik). Jurnal Komunikasi Dan Pendidikan Islam, 6(2), 143-161. Retrieved from https://journal.staimsyk.ac.id/index.php/almanar/article/view/29

Iriyansah, M. R. (2019). Ngoko And Krama In Non Formal Diglosia Situation In Lamongan ( A Sociolinguistic Study ) Ragam Ngoko Dan Krama Dalam Situasi Diglosia Informal Ranah Ketetanggaan Di Lamongan (Suatu Kajian Sosiolinguistik ). Jurnal Kata, 3(1), 76-82. https://doi.org/10.22216/jk.v3i1.3954

Rokhman, F. (2015). Kode Bahasa Dalam Interaksi Sosial Santre Kajian Sosiolinguistik Di Pesantren Banyumas. Litera. https://doi.org/10.21831/ltr.v3i1.6772

Rustono. (1999). Pokok-Pokok Pragmatik. Semarang: CV IKIP Semarang Press.

Simarmata, M. Y. (2012). Pemilihan Kode Dalam Masyarakat Dwibahasawan Pada Masyarakat Batak Toba Di Desa Binjai, Kecamatan Tayan Hulu, Kabupaten Sanggau Pontianak, Kalimantan Barat (Sebuah Kajian Sosiolinguistik). Retrieved from https://digilib.uns.ac.id/

Sumarsono. (2013). Sosiolinguistik. Yogyakarta: SABDA.

Wahab, L. A. (2013). Fenomena Diglosia dalam Masyarakat Keturunan Arab Empang. Al Izzah, 8(2), 147-165. https://doi.org/http://dx.doi.org/10.31332/ai.v8i2.172

Yusuf, M. (2017). Pemilihan Bahasa Kelompok Tutur Pendatang Jawa Di Landasan Ulin, Banjarbaru. Jurnal Bahasa, Sastra Dan Pembelajarannya, 7(1), 22-34. https://doi.org/http://dx.doi.org/10.20527/jbsp.v7i1.3764 